\title{
Kajian Hukum Islam terhadap Kepemimpinan Gubernur Non Muslim di Negara Kesatuan Republik Indonesia
}

\author{
Husnaeni \\ Institut Agama Islam Negeri (IAIN) Bone \\ husnaenibone@gmail.com
}

\begin{abstract}
Abstrak
Penelitian ini bertujuan untuk mengetahui konsep dan pengaruh yang ditimbulkan dari adanya pemimpin non muslim di Negara kesatuan Republik Indonesia. Untuk memperoleh data dari masalah tersebut, penulis menggunakan jenis penelitian kepustakaan (library research) dengan pendekatan yuridis normatif. Data yang diperoleh kemudian diolah dengan menggunakan metode deskriptif analisis untuk menganalisis dan menjelaskan terkait hukum islam dan pemimpin non muslim Hasil penelitian menunjukan bahwa pemimpin adalah individu yang memiliki pengaruh terhadap individu lain dalam sebuah sistem untuk mencapai tujuan bersama. Kepemimpinan tidak hanya dipertanggungjawabkan dihadapan Allah swt. Rasulullah sebagai pemimpin teladan yang menjadi model ideal pemimpin, Rasulullah dikaruniai empat sifat utama yaitu, sidiq, amanah, tabligh dan fatanah. Dalam perspektif hukum islam dan kepemimpinan gubernur non muslim di Negara kesatuan Republik Indonesia. Hukum islam adalah seperangkat peraturan berdasarkan wahyu Allah dan sunnah rasul tentang tingkah laku manusia mukallaf yang diakui dan diyakini mengikat untuk semua yang beragama islam, yang dimaksudkan segala sesuatu yang terdapat di dalam al-qur'an dan sunnah. Adapun Kepemimpinan dalam pandangan Islam tidak memisahkan secara dikotomis Negara dan agama, umara dan ulama. Agama dan ulama memberi warna negara karena pemimpin merupakan sebuah amanat yang diberikan kepada orang yang benar-benar ahli, berkualitas dan memiliki tanggungjawab yang jelas dan benar serta adil, jujur dan bermoral baik, menerima kritik membangun dan ditambah berkolaborasi dengan ulama. Pemimpin yang adil itu syarat utamanya harus beriman dan taat menjalankan ajaran agama. Di luar itu, tidak bisa disebut pemimpin yang adil ('adalah). Tanggung jawab tidak hanya kepada rakyat tetapi juga kepada Allah di akhirat.
\end{abstract}

\section{Kata Kunci : Kajian Hukum Islam, dan Kepemimpinan Gubernur Non Muslim di Negara Kesatuan Republik Indonesia}




\section{PENDAHULUAN}

Islam sebagai agama bagi setiap muslim, menjadi kerangka acuan paripurna untuk seluruh kehidupannya. Islam dengan demikian merupakan agama penyatu yang lengkap (a religion of Complete integration). ${ }^{248}$ Dalam konteks sejarah, untuk pertama kalinya kita melihat ajaran mengenai pembangunan manusia melalui integrasi yang utuh dengan dirinya sendiri, dengan masyarakat, dengan alam semesta, dan bahwa integrasi ini berdasarkan atas adanya Allah SWT.Tuhan Yang Maha Esa dalam seluruh eksistensinya. ${ }^{249}$ Islam dan politik, adalah dua kata yang tidak pernah sepi menjadi perbincangan (discourse) dalam khazanah intelektual muslim. Dalam rentang realitas sejarah Islam, ${ }^{250}$ banyak dari para pemikir Islam klasik, modern dan neo modern, yang mencoba memberikan sebuah penjelasan hubungan antara Islam dan politik, dengan beragam cara pendekatan dan metode yang berbeda-beda.

Salah satu persoalan yang kerap kali diperdebatkan ialah tentang kepemimpinan non muslim. Perdebatan tentang persoalan ini kemudian mengarah pada konsep tentang hubungan antara agama dan Negara. Dalam momentum pemilu legislatif, pemilu presiden, atau isu pilkada di setiap daerah, saat ada pemimpin non muslim yang mencalonkan, isu kepemimpinan non muslim kembali digulirkan. Dalam era globalisasi ini, masalah kepemimpinan bukan hanya masalah lokal atau wilayah suatu negara saja. Pengangkatan seorang pemimpin lebih banyak dipengaruhi oleh permasalahan dunia politik. Apalagi dengan adanya sistem demokrasi, seorang

\footnotetext{
${ }^{248}$ Hakim Mohammad Said, ,Moralitas politik: Konsep mengenai Negara', dalam A.E. Proyono (ed), Islam Pilihan Peradaban, (Yogyakarta: Shalahuddin Press, 1884), cet. ke-1, h. 72.

${ }^{249}$ Hakim Mohammad Said, ,Moralitas politik: Konsep mengenai Negara (Yogyakarta: Shalahuddin Press, 1884), cet. ke-1, h. 72.

${ }^{250}$ John L. Esposito, Islam and Politics, terj. Joesoef Sou’yb, (Jakarta: Bulan Bintang, 1990), h. xxi.
} 
pemimpin yang akan diangkat adalah yang mempunyai dukungan terbanyak. Dalam dunia politik, bukan hanya yang beragama Islam tetapi banyak pula yang beragama non muslim.

Terkait dengan memilih pemimpin, banyak kalangan yang pro dan kontra terhadap memilih pemimpin yang non muslim khususnya di negara mayoritas muslim. Timbul sebuah pertanyaan, "Bolehkan memilih seorang non-muslim menjadi pemimpin di daerah yang mayoritas muslim"?, pertanyaan ini sangat tepat sekali untuk konteks saat ini. Bagaimana Al-qur'an sendiri berbicara mengenai hubungan muslim dengan non-muslim dalam ranah politik ini. Secara umum ada dua klasifikasi pemikiran dalam masalah ini. Pertama, mereka yang melarang. Kedua mereka yang membolehkan adanya pemimpin dari kalangan non-muslim.

Di dalam pemerintahan warga negara berperan penting demi jalannya pemerintahan yang baik. Karena itu masyarakat memiliki beberapa hak-hak dalam pemerintahan yang berupa hak politik. Seperti memberikan suaranya ketika pemilu, kemudian hak untuk memilih dan hak untuk dipilih sebagai kepala daerah, wakil rakyat atau memegang peranan di pemerintahan. ${ }^{251}$ Hak-hak kewarganegaraan menjadi persoalan penting dalam pemerinthan Islam. Dalam Islam tidak dikenal perbedaan kelas. Karena Al-qur'an mengakui prinsip kemuliaan manusia (karamatul insan). ${ }^{252}$ Agar kehidupan suatu umat berjalan secara teratur dan hubungan sesama manusia berjalan dengan rukun dan damai. Maka diangkatlah seorang pemimpin yang diberikan kewenangan untuk memimpin pelaksanaan aturan yang telah ditetapkan.

${ }^{251}$ Mujar Ibnu Syarif, Hak-Hak politik minoritas non-muslim dalam komunitas Islam (Bandung: Angkasa, 2003), h.1.

${ }^{252}$ Ahmad Vaezi, Agama Politik Islam Nalar Politik Islam (Jakarta: citra,2006), h. 11.

Jurnal Al-Dustur; VOLUME 2 NO 2, DESEMBER 2019 
Mengingat peranannya yang sangat signifikan, maka dalam Islam pengangkatan seorang pemimpin adalah sesuatu yang sangat urgen. ${ }^{253}$

Seorang pemimpin mempunyai tanggung jawab yang sangat besar, bukan hanya menjadi pengarah dalam pelaksanaan kebijakan yang dibuat oleh manusia. Tetapi ia merupakan khalifah di dunia yang berperan memimpin dan mengarahkan umat manusia agar mereka melaksanakan aturan negara dan hukum Allah. ${ }^{254}$ Pemerintahan yang baik dalam menyelenggarakan kekuasaan negara harus berdasarkan pada (ketertiban dan kepastian hukum dalam pemerintahan, perencanaan dalam pembangunan, pertanggungjawaban baik oleh pejabat dalam arti luas maupun oleh pemerintahan, pengabdiaan pada kepentingan masyarakat, dan untuk sebesarbesar kemakmuran rakyat). ${ }^{255}$

Adapun ayat yang dapat dijadikan dasar tentang hubungan politik muslim dengan non muslim yaitu di surah Al- Maidah ayat 51 ialah :

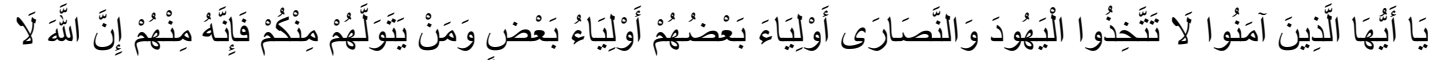

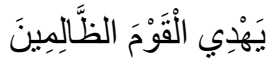

Terjemahan :

"Hai orang-orang yang beriman, janganlah kamu mengambil orang-orang Yahudi dan Nasrani menjadi pemimpin-pemimpin(mu); sebahagian mereka adalah pemimpin bagi sebahagian yang lain. Barangsiapa diantara kamu mengambil mereka menjadi pemimpin, maka sesungguhnya orang itu termasuk golongan mereka. Sesungguhnya Allah tidak memberi petunjuk kepada orangorang yang zalim. ${ }^{256}$

${ }^{253}$ Ahmad Vaezi, Agama Politik Islam Nalar Politik Islam,h. 11.

${ }^{254}$ Ahmad Vaezi, Agama Politik Islam Nalar Politik Islam,h. 12.

${ }^{255}$ Beni Ahmad Saebani, Fiqih Siyasah Terminologi dan Lintasan Sejarah Politik Islam Sejak Muhammad saw. Hingga Al-Khulafa Ar-Rasyidun (Bandung: CV Pustaka Setia, 2015), h. 123.

${ }^{256}$ Departemen Agama Republik Indonesia, Al-Qur'an Dan Terjemahan (Semarang: PT. Toha Putra, 2002), h. 155. 
Hak politik muslim dan non muslim sama di depan hukum, hanya saja untuk pemegang kekuasaan lebih diutamakan seorang muslim karena hukum Islam hanya diyakini oleh umat Islam, sedangkan non muslim hanya ikut mengaplikasikannya. ${ }^{257}$ Umara dan ulama dalam konteks di atas merupakan pengemban tugas khalifah dalam arti menjadi pengemban amanat Allah dalam memelihara dan melaksanakan amanatnya. $^{258}$

Dalam Islam, kepemimpinan merupakan salah satu elemen penting. Wajib hukumnya mengangkat satu orang 'amir (pemimpin) yang adil dalam suatu komunitas masyarakat, agar komunitas sosial tersebut mampu menegakkan kebenaran dan keadilan.Sebab penegakan keadilan tidak mungkin dicapai kecuali dengan kekuasaan/otoritas seorang pemimpin yang taat pada ajaran agamanya.Karena itu, syarat yang paling mendasar seorang pemimpin disebut adil adalah dilihat dari keimannya dan komitmennya menjalankan perintah agama.Jika tidak beriman, tidak mungkin adil.Sebab, kekufuran itu kedzaliman, atau ketidakadilan.Jadi, adil itu tidak sekedar membagi sama rata, dan sama rasa. Tetapi adil itu menempatkan sesuatu pada posisinya. ${ }^{259}$

Jika dilihat dari kenyataan yang ada di Negara mayoritas muslim telah terjadi orang non muslim dijadikan pemimpin, pada dasarnya jika dilihat hak asasi manusia (HAM) maka tidak ada salahnya jika seseorang non muslim ingin mencalonkan diri

\footnotetext{
${ }^{257}$ Abu al-A A la al-Maududi, "The Islamic Law and Costitution”, (Lahore: Islamic Publications, 1960), h. 39

${ }^{258}$ Imam Ghazali Said, "Solusi Hukum Islam: Keputusan Muktamar, Munas dan Konbes Nahdlatul Ulama”, (Surabaya: Diantama, 2006), h. 645

${ }^{259}$ Ahmad Kholili Hasib, “Islam dan Kepemimpinan Non Muslim”https://www. hidayatullah. com/artikel/tsaqafah/read/2016/10/17/102792/islam-dan-kepemimpinan-nonmuslim.html.
} 
menjadi pemimpin dikarenakan setiap memiliki hak yang seimbang dan hak yang sama serta memiliki hak untuk mencalonkan diri menjadi pemimpin ataupun memilih dan dipilih oleh siapa saja yang ingin memilih orang non muslim tersebut sebagai pemimpin. ${ }^{260}$

Kepemimpinan dalam pandangan Islam tidak memisahkan secara dikotomis Negara dan agama, umara dan ulama. Agama dan ulama memberi warna negara karena pemimpin merupakan sebuah amanat yang diberikan kepada orang yang benar-benar ahli, berkualitas dan memiliki tanggungjawab yang jelas dan benar serta adil, jujur dan bermoral baik, menerima kritik membangun dan ditambah berkolaborasi dengan ulama. Pemimpin yang adil itu syarat utamanya harus beriman dan taat menjalankan ajaran agama. Di luar itu, tidak bisa disebut pemimpin yang adil ('adalah). Tanggung jawab tidak hanya kepada rakyat tetapi juga kepada Allah di akhirat. ${ }^{261}$

Memahami sebab kedudukan yang tinggi yang dijadikan Islam untuk berprinsip "berlaku adil" sebagai sarana pengikat antara semua prinsip- perinsip umum mendasar dan kaidah-kaidah konstitusional menyeluruh, seperti prinsip-prinsip musyawarah, persamaan hak, kebebasan dan hak asasi manusia. ${ }^{262}$ Konsepsi kepemimpinan pemerintahan maka yang dimaksudkan dalam pemimpin disini adalah pemimpin pada ketiga cabang pemerintahan, yaitu eksekutif, legislatif, yudikatif. Dalam tingkatan eksekutif atau pemerintahan dalam arti sempit maka kepemimpinan

\footnotetext{
${ }^{260}$ Majda El Muhtaj, “Hak Asasi Manusia dalam Konstitusi Indonesia”. Cet.1.(Jakarta: Kencana,2005), h.11.

${ }^{261}$ Ahmad Kholili Hasib, “Islam dan Kepemimpinan Non Muslim”. https: //www. hidayatullah. com/artikel/tsaqafah/read/2016/10/17/102792/islam-dan-kepemimpinan-nonmuslim.html.

${ }^{262}$ Farid abdul Khalik, Fikih Politik Islam(Jakarta:Sinar Grafika Ofset, 2005), h.208. 
pemerintahan dipegang oleh pemimpin pemerintah mulai dari tingkat daerah sampai tingkat negara yaitu Lurah/Kades, Camat, Wali Kota/ Bupati, Gubernur dan Presiden.

Ditelaah lebih jauh dalam konteks kepemimpinan akan sangat luas, karena dalam kempimpinan di sebuah negera ada banyak sekali , maka penulis dalam hal ini akan mambahas perihal kajian hukum islam dalam memilih seorang pemimpin yang menjabat dalam suatu pemerintahan negara, dari kalangan mana siapapun boleh menjadi kepala negara, asalkan ia mampu melaksanakannya. Kepala negara ditentukan berdasarkan pemilihan umat islam sendiri. Merekalah yang paling tahu tentang keadan mereka dan hal-hal yang mereka pilih. ${ }^{263}$ Berdasarkan dari latar belakang di atas, maka dapat dirumuskan beberapa rumusan masalah sebagai berikut Bagaimana konsep hukum islam mengenai kepemimpinan gubernur non muslim di negara kesatuan Republik Indonesia dan Bagaimana pengaruh yang ditimbulkan kepemimpinan gubernur non muslim di negara kesatuan Republik Indonesia.

\section{TINJAUAN PUSTAKA}

Untuk mengetahui secara sistematis tentang isi dan makna judul tersebut maka penulis merumuskan tentang pengertian judul.

Kajian adalah hasil mengkaji. ${ }^{264}$

Hukum Islam adalah seperangkat peraturan berdasarkan wahyu Allah dan sunah Rasul tentang tingkah laku manusia mukallaf yang diakui dan diyakini

\footnotetext{
${ }^{263}$ Muhammad Iqbal, Fiqih Siyasah-Konstektualisasi Doktrin Politik Islam (Indonesia: Prenadamedia Group, 2014), h. 144.

${ }^{264}$ Hasan Alwi, Kamus Besar Bahasa Indonesia, Edisi Ketiga (Jakarta: Balai Pustaka 2002), h. 491.
}

Jurnal Al-Dustur; VOLUME 2 NO 2, DESEMBER 2019 
mengikat untuk semua yang beragama Islam, yang dimaksud di sini hukum Islam adalah segala aturan yang terdapat di dalam Al-Qurean dan Hadits. ${ }^{265}$

Kepemimpinan adalah orang yang memimpin atau seseorang yang menggunakan kemampuannya, sikapnya, nalurinya dan kepribadiannya yang mampu menciptakan suatu keadaan sehingga orang lain yang dipimpinnya saling bekerjasama untuk mencapai tujuan. ${ }^{266}$

Non muslim adalah orang yang tidak beragama Islam. Pengertian non muslim dapat dilihat dari pengertian muslim dengan mendapat kata imbuhan non yang berarti tidak atau bukan. Maka non muslim adalah tidak atau bukan beragama Islam. ${ }^{267}$ Jadi Pemimpin non muslim adalah seorang pemimpin yang bukan atau tidak beragama Islam.

Gubernur adalah kepala pemerintahan tingkat provinsi. ${ }^{268}$

Muslim berasal dari kata salima-yaslamu artinya orang-orang yang berserah diri kepada peraturan Allah SWT dengan sepenuh pengabdian (beragama islam). ${ }^{269}$ Muslim adalah penganut agama Islam. ${ }^{270}$

Negara adalah kelompok sosial yang menduduki wilayah atau daerah tertentu yang di organisasi di bawah lembaga politik dan pemerintah yang efektif mempunyai kesatuan politik berdaulat sehingga berhak menentukan tujuan nasionalnya. ${ }^{271}$

${ }^{265}$ Amir Syarifudin, Garis-garis Besar Fiqih, (Jakarta: Prenada Media, 2003), h. 9.

${ }^{266}$ M. Dhiauddin Rais, Teori Politik Islam, (Jakarta: Gema Insani, 2001), h. 40.

${ }^{267} 6$ Pusat Pembinaan dan Pengembangan Bahasa, Kamus Besar Bahasa Indonesia, (Jakarta: Balai Pustaka, 1994), h. 692.

${ }^{268}$ Hasan Alwi, Kamus Besar Bahasa Indonesia, (Jakarta: Balai Pustaka 2002), h. 372.

${ }^{269}$ Ahsin W.Al-Hafidz, Kamus Ilmu Al-Qur"an (Jakarta: Sinar Grafika Ofset, 2006), h. $205 .$.

${ }^{270}$ Hasan Alwi, Kamus Besar Bahasa Indonesia, (Jakarta: Balai Pustaka 2002), h. 767

${ }^{271}$ Hasan Alwi, Kamus Besar Bahasa Indonesia, (Jakarta: Balai Pustaka 2002), h. 777. 


\section{METODE PENELITIAN}

Dalam penelitian skripsi ini, penulis menggunakan metode analisis deskriptif. Artinya metode analitis deskriptif digunakan untuk menggambarkan secara objektif materi yang akan dibahas. Metode analitis digunakan untuk mendapat dan mengetahui implikasi dari Kajian Hukum Islam terhadap Kepemimpinan Gubernur Non-Muslim dalam Negara Kesatuan Republik Indonesia.

Jenis penelitian hokum normatif yang nama lainnya adalah penelitian hukum doktrinal yang disebut juga sebagai penelitian perpustakaan atau studi dokumen karena penelitian ini dilakukan atau ditujukan hanya pada peraturanperaturan yang tertulis atau bahan-bahan hukum yang lain. ${ }^{272}$ Pada intinya penelitian yang dilakukan dengan cara meneliti bahan-bahan pustaka atau data sekunder yang terdiri dari bahan hukum primer, bahan hukum sekunder dan bahan hukum tersier.

1. Jenis dan Pendekatan Penelitian

a. Jenis Penelitian

Penelitian ini menggunakan penelitian pustaka (library research), yaitu penelitian dengan melakukan penelusuran di perpustakaan kampus, perpustakaan daerah, dan kedai baca. Untuk mendapatkan data yang sesuai dengan objek penelitian, penulis membaca buku-buku tentang kepemimpinan, hukum, jurnal, skripsi dan literatur yang berkaitan dengan objek penelitian. ${ }^{273}$ Kemudian penulis memilah-milah data yang sesuai dengan objek penelitian.

${ }^{272}$ Soerjono Soekanto, dan Sri Mamudji, Penelitian hukum normatif, ( Jakarta: PT. Raja Grafindo Persada, 2004), Cet. Ke-8, h. 14.

${ }^{273}$ Sutrisno Hadi, Metodologi Research (Yogyakarta: Andi Offset,1990), h. 9. 
b. Pendekatan Penelitian

Keterkaitannya dengan penelitian normative, pendekatan yang digunakan dalam penulisan hokum menurut Peter Mahmud Marzuki adalah sebagai berikut: ${ }^{274}$

1. Pendekatan kasus (case approach)

2. Pendekatan perundang-undangan ( statute approach)

3. Pendekatan historis ( historical approach)

4. Pendekatan perbandingan ( comparative approach)

5. Pendekatan konseptual (conceptual approach)

Adapun pendekatan yang digunakan penulis dari beberapa pendekatan perundang-undangan (statute approach) dan pendekatan kasus ( the case approach). Pendekatan perundang-undangan adalah pendekatan yang dilakukan dengan menelaah semua undang-undang dan regulasi yang bersangkutpaut dengan isu hukum yang ditangani. Pendekatan kasus adalah pendekatan yang dilakukan dengan cara melakukan telaah terhadap kasus-kasus yang berkaitan dengan isu yang dihadapi yang telah menjadi putusan pengadilan yang telah mempunyai kekuatan hukum yang tetap. ${ }^{275}$

Pendekatan yang dilakukan dalam penelitian ini yaitu pendekatan keilmuan. Pendekatan keilmuan melahirkan ragam pendekatan sesuai dengan cabang-cabang ilmu yang ada. Misalnya pendekatan ilmu

${ }^{274}$ Peter Mahmud Marzuki, Penelitian Hukum. (Jakarta: Kencana Prenada Media Group, 2011), h,93.

${ }^{275}$ Peter Mahmud Marzuki, Penelitian Hukum. (Jakarta: Kencana Prenada Media Group, 2011), h. 24. 
kesyariahan atau hukum Islam. Pendekatan yang dilakukan dalam penelitian ini yaitu yuridis normatif dan pendekatan religius-teologis.

Pendekatan yuridis-normatif adalah pendekatan yang dilakukan berdasarkan buku-buku dengan cara menelaah teori-teori dan konsepkonsep yang berhubungan dengan penelitian ini yaitu kajian hukum islam terhadap kepemimpinan gubernur non muslim dalam Negara kesatuan Republik Indonesia.

Pendekatan religius-teologis yaitu menguraikan pandangan agama, khususnya agama Islam yang terkait dengan kepemimpinan non muslim.

2. Data dan Sumber Data

a. Data

Sesuai dengan pendekatan penelitian yaitu yuridis-normatif maka data-data yang hendak di kumpulkan adalah data- data yang meliputi bahan buku primer, bahan buku sekunder dan bahan buku tersier. ${ }^{276}$

b. Sumber Data

Untuk memperoleh data yang akurat, penulis menggunakan teknik studi pustaka sebagai salah satu upaya untuk memperoleh dokumendokumen tertulis yang terdiri dari:

1. Bahan hukum primer adalah bahan hukum primer yang digunakan terdiri dari peraturan perundang-undangan, catatan resmi, risalah dalam pembuatan perundang-undangan dan

\footnotetext{
${ }^{276}$ Soejono Soekanto, Metode Penelitian Hukum.(T.Cet; Jakarta: UI-pres, 1986), h. 52 Jurnal Al-Dustur; VOLUME 2 NO 2, DESEMBER 2019
} 
putusan hakim. ${ }^{277}$ Dalam penelitian ini bahan hukum primer yang digunakan adalah sebagai berikut:

a. Undang-Undang Dasar 1945

b. Kitab Undang-Undang Hukum Perdata (KUHPerdata)

c. Kitab Undang-Undang Hukum Pidana (KUHPidana)

2. Bahan hukum sekunder adalah bahan buku teks, karena buku teks berisi mengenai prinsip-prinsip dasar ilmu hukum dan pandangan-pandangan klasik para sarjana yang mempunyai kualifikasi tinggi. ${ }^{278}$ Dalam penelitian ini bahan hukum sekunder yang digunakan meliputi :
a. Buku-buku ilmiah;
b. Makalah-makalah;
c. Jurnal ilmiah;
d. Artikel ilmiah.

3. Bahan hukum tersier adalah bahan yang memberikan petunjuk maupun penjelasan terhadap bahan hukum primer dan sekunder. Dalam penelitian ini bahan hukum tersier yang digunakan meliputi:

a. Kamus Besar Bahasa Indonesia

b. Kamus Hukum

c. Situs Internet yang berkaitan dengan kepemimpinan gubernur non muslim di negara kesatuan republik Indonesia.

${ }^{277}$ Peter Mahmud Marzuki, Penelitian Hukum. (Jakarta: Kencana Prenada Media Group, 2011), h. 141.

278 Peter Mahmud Marzuki, Penelitian Hukum. (Jakarta: Kencana Prenada Media Group, 2011), h. 142. 
1. Teknik pengumpulan data

Teknik pengumpulan data ini berguna untuk mendapatkan data-data sebagaimana tersebut diatas di gunakan, teknik pengumpulan data sebagai berikut;

a. Data primer merupakan data utama dari objek yang diteliti, pengumpulan data ini dilakukan dengan cara studi kepustakaan. Tujuan dari studi kepustakaan pada dasarnya merupakan jalan pemecahan permasalahan penelitian. Studi ini dilakukan terlebih dahulu agar data yang di dapat dijadikan dasar pedoman melakukan anlisis data. ${ }^{279}$

b. Data sekunder merupakan data yang diperoleh secara tidak langsung dengan yang aslinya. ${ }^{\mathbf{2 8 0}}$ Pengumpulan data-data sekunder ini penulis lakukan dengan cara mencari buku-buku yang berkaitan dengan judul penelitian. Dengan cara ini peneliti dapat mendapatkan data yang dibutuhkan untuk memperjelas kembali data primer.

c. Data tersier merupakan data penunjang untuk data primer dan sekunder. Data sekunder ini di gunakan untuk memperjelas kata- kata yang sulit di pahami dalam penelitian ini. Pengumpulan data ini di lakukan dengan cara mencari dikamus besar bahasa Indonesia maupun buku-buku ensiklopedia.

2. Teknik analisis data

Menurut Bogdan dan Biklen yang dikutip dari Moleong Lexy analisis data adalah upaya yang dilakukan dengan jalan bekerja dengan data-data yang diolah dan

${ }^{279}$ Soejono Soekanto dan Sri Manudji,Penelitian hukum Normatif Suatu Tinjauan Singkat (Cet. III; Jakarta: Rajawali Press, 1990),h. 55.

${ }^{280}$ Louis Gootshalk, Understanding History a Primer Of Historical Method, (Jakarta: UI Press, 1985), Penerjemah : Nugroho Noto Susanto, h. 95. 
memilah-milahnya menjadi satuan yang dapat dikelolah, mensistematikannya, mencari dan menentukan pola, menemukan apa yang penting dan apa yang dipelajari, dan memutuskan apa yang dapat diceritakannya padaoranglain. ${ }^{281}$

Dalam suatu penelitian ilmiah terdapat dua macam teknik analisis data, yaitu teknik analisis data kuantitatif dan teknik analisis data kualitatif.Pada penelitian ini, penulis menggunakan teknik analisis data kualitatif dan analisis isi (conten analysis). ${ }^{282}$ Teknik analisis data kualitatif dilakukan melalui 4 cara yang sesuai dengan prosedur dan teknis pengolahan data kualitatif yaitu sebagai berikut:

1. Dilakukan pemilahan dan juga penyusunan klasifikasi data.

2. Dilakukan penyuntingan data dan juga pemberian kode data untuk membangun kinerja analisis data.

3. Dilakukan konfirmasi data yang memerlukan verifikasi data dan pendalaman data.

4. Dan terakhir dilakukan analisa data sesuai dengan konstruksi pembahasan hasil penelitian. ${ }^{283}$

\section{HASIL PENELITIAN DAN PEMBAHASAN}

\section{Pengaruh Hukum Islam dengan adanya Kepemimpinan Gubernur Non Muslim di Negara Kesatuan Republik Indonesia}

${ }^{281}$ Moleong Lexy, Metode Penelitian Kualitatif(cet. I; Bandung: Remaja Rozda Karya, 2009), h. 219.

${ }^{282}$ Abdul Kadir Muhammad, Hukum dan Penelitian Hukum, (Bandung: Citra Adtya Bakti, 2004), h. 127.

${ }^{283}$ Abdul Kadir Muhammad, Penelitian Hukum, (Bandung: Citra Adtya Bakti, 2004), h. 145. 
Pemimpin dan pemerintahan ini nampaknya menjadi persoalan yang banyak menyedot perhatian para pemikir islam terutama dalam hukum mengangkat pemimpin gubernur non muslim menjadi pemimpin. Sehingga menimbulkan banyak pendapat dan perdebatan dalam masyarakat dalam memilih pemimpin non muslim tersebut. Semenjak zaman lahirnya islam sampai dengan zaman modern sekarang ini bahkan mungkin akan berlanjut pada zaman yang akan mendatang. Memang tidak dapat dipungkiri bahwa manusia diciptakan oleh Allah, dibekali dengan beberapa kelebihan dan kecenderungan untuk memahami suatu ayat al-qur'an yang berbeda satu sama lain, sebagai isyarat yang harus dipegang dalam kehidupan sehari-hari termasuk dalam hal memilih pemimpin.

Menurut pendapat Syaikh Imam Qurtubi, pemimpin harus dipegang oleh kaum muslimin, dan sangat berbahaya apabila pemimpin dipercayakan kepada kaum non muslim. Di dalam kitab Tafsiratul Qurtubi, beliau menyatakan pada zaman sekarang ini keadaan sudah terbalik dan berubah sedemikian rupa, hingga orangorang islam lebih mempercyakan segalanya kepada orang-orang kafir, dan keadaan kaum muslimin pun semakin memburuk dan terpuruk. ${ }^{284}$

Menurut Hasbias Siddiqi, kerja sama, bantu membantu, dan bersahabat setia diantara dua orang yang berlainan agama untuk kemaslahatan dunia, yang demikian itu tidak dilarang. Yang dilarang adalah kita bersahabat setia dengan Yahudi dan Nasrani dalam hal-hal yang merusak atau bertentangan dengan kemaslahatan para mukmin seperti ungkapan beliau dalam tafsir al-qur'anulmajid an-nur, Tuhan hanya melarang kamu berkawan setia dengan orang-orang yang terang-terangan

\footnotetext{
${ }^{284}$ Syeikh Imam Qurtubi, Tafsir Al-Qurtubi, terjemahan Dudi Rosyadi,( Jakarta: Pustaka Azzam, Edisi ke-IV, 2008), h. 446.
}

Jurnal Al-Dustur; VOLUME 2 NO 2, DESEMBER 2019 
memusuhimu, yang memerangimu, yang mengusir kamu atau membantu orang-orang yang mengusirmu seperti yang dilakukan orang musyrik Makkah. ${ }^{285}$

Menurut Sayyid Qutbdi dalam Tafsirannya beliau beranggapan bahwa agama islam menyuruh pemeluknya agar melakukan toleransi dan melakukan pergaulan yang baik dengan ahli kitab. Khususnya, mereka yang mengatakan " sesungguhnya kami adalah orang-orang Nasrani" akan tetapi al-qur'an melarang mereka memberikan loyalitas dan kesetiaan kepada mereka semua. Karena toleransi dan bergaul dengan baik itu adalah masalah akhlak, dan perilaku, sedangkan masalah wala' berarti pertolongan atau bantu membantu antar satu golongan dan golongan lain. Sedangkan hal ini, tidak ada bantu-membantu dan tolong-menolong antara kaum muslimin dan ahli kitab sebagaimana halnya dengan orang kafir. ${ }^{286}$

Menurut Ahmad Musthafa Al-Maraghi mengenai pengangkatan pejabat non muslim tidaklah masalah, memang banyak ayat al-qur'an yang secara tegas melarang kaum muslimin untuk mengangkat non muslim menjadi walinya, tetapi ada alas analasan yang melarangnya, secara umum adalah pelarangan mengambil non muslim sebagai teman dalam suatu hal yang membahayakan kaum muslimin, seperti membuka rahasia-rahasia khusus yang berkaitan dengan urusan-urusan agama, bersekongkol untuk memerangi kaum muslimin lainnya. ${ }^{287}$

Ada beberapa ayat al-qur'an yang oleh sebagian musafir dijadikan pegangan sebgai umat muslimin untuk tidak menghendaki dan tidak mau dipimpin oleh non

${ }^{285}$ Teungku Muhammad Hasbi ash-Shiddiqy, Tafsir al-qur'anul majid an-nur.(Semarang:PT. Pustaka Rizki Putra, 2000), h. 4193.

${ }^{286}$ Sayyid Quthb, Tafsir Fi Zhilalil Qur'an, terj. As'ad Yasin, cet 1( Jakarta: Gema Insani Pres, 2002), h. 265

${ }^{287}$ Ahmad Musthofa al-Maraghi, terjemahan tafsir al-maragi, terj. Bagrun Abu Bakar ( Semarang: PT. Toha Putra 1993), h. 250. 
muslim, terutama terkait dengan urusan-urusan publik. Ayat-ayat al-qur'an QS. Al Baqarah ayat 120, QS. Ali Imran ayat 28, QS. An-Nisa ayat 89, 139, 144.

Hukum memilih pemimpin non muslim seperti Bupati/Walikota dan Wakil Bupati/Wakil Walikota, Gubernur/ Wakil Gubernur, Presiden/ Wakil presiden adalah haram, sebab memilihnya berarti mengangkatnya sebagai dan menjadikan kaum muslimin di bawah kekuasaan, dominasi, dan superioritasnya. ${ }^{288}$ Begitu juga memilih pemimpin yang tidak memenuhi syarat-syarat ${ }^{289}$ atau tidak memilih sama sekali padahal ada calon yang memenuhi syarat hukumnya adalah haram. ${ }^{290}$ Orang Islam tidak boleh menguasakan urusan kenegaraan kepada orang non-Muslim kecuali dalam keadaan darurat, sepanjang penguasaan urusan kenegaraan kepada non-Muslim itu membawa manfaat. ${ }^{291}$ Larangan yang dikandung agar tidak menjadikan orangorang yang bukan seakidah sebagai pemimpin, karena identitas mereka sebagai kelompok agama lain. Karena seharusnya loyalitas Muslim hanyalah bagi umat Islam. ${ }^{292}$ Kepemimpinan tidak boleh diserahkan kepada orang kafir termasuk ketika ada pemimpin Muslim yang melakukan kekufuran, maka dia harus dilengserkan. ${ }^{293}$

Sesungguhnya pemimpin dilengserkan karena kekufuran yang mereka lakukan, para ulama bersepakat wajib kaum muslimin untuk melengserkannya. Siapa

${ }^{288}$ Tim Keputusan Bathsul Masail ke 2 PCNU kota Surabaya Periode 2015-2020 M, Di masjid Sabilul Muthahahirin (Surabaya: Brata Jaya,2016), h. 2.

${ }^{289}$ Himpunan Fatwa MUI 1975, Memilih Pemimpin yang Beriman dan Bertaqwa,(Jakarta: Penerbit Erlangga, 2011), h. 878.

${ }^{290}$ Himpunan Fatwa MUI 1975, Memilih Pemimpin yang Beriman dan Bertaqwa,(Jakarta: Penerbit Erlangga, 2011), h. 878.

${ }^{291}$ Imam Ghazali Said, Solusi Hukum Islam: Keputusan Muktamar, Munas, dan Konbes Nahdathul Ulama, ( Surabaya: Diantama, 2006), h.562

${ }^{292}$ Yusuf Qardawi, Fatwa-fatwa Kontemporer, (Jakarta:GIP, 2001), h. 570

${ }^{293}$ Abu Fadhl Qadi Iyadh, Syarah Sahih Muslim, al-Nawawi,(Qahra:Dar al-Kutub), jilid 6, h. 315 
yang mampu melakukan itu, maka dia mendapat pahala. Dan siapa yang basa-basi dengan mereka, maka mereka medapat dosa. Dan siapa yang tidak mampu, wajib baginya untuk hijrah dari daerah itu. ${ }^{294}$ Untuk itu, pemimpin hendaknya hidup dan bekerja dengan visi yang jelas, serta tidak gampang tergoda dengan keuntungan jangka pendek, ataupun kesempatan yang tidak jujur untuk mendapatkan keuntungan yang singkat. ${ }^{295}$ Meski pada hakikatnya para pihak yang terlibat dalam kepemimpinan sadar benar bahwa tidak semua kepentingan masyarakat dapat dipuaskan. ${ }^{296}$ Dari sekian banyak ideologi dan sistem untuk mengelola negara, kepemimpinan Islam lebih mampu mengkoordinir banyak perbedaan demi terwujudnya konsensus. Lagi pula Siyasah al-Syariyyah lebih merupakan sebuah gagasan subtansif yang dapat mengkomodasi keberagaman didalam batasan-batasannya. ${ }^{297}$

\section{Pengaruh Hukum Positif dengan adanya Kepemimpinan Gubernur Non Muslim di Negara Kesatuan Republik Indonesia}

Di Indonesia hak untuk dipilih merupakan bagian dari HAM yaitu dalam hak asasi politik. Hak asasi Politik adalah hak ikut serta dalam Pemerintahan, hak pilih maksudnya hak untuk dipilih contohnya seperti seorang non-Muslim yang mencalonkan diri sebagai Gubernur di Negara mayoritas Muslim ini. Maka hukum mengangkat pemimpin non-Muslim jika dilihat dalam Undang-undang Pilkada Nomor 10 tahun 2016 tentang pemilihan Gubernur, Bupati, dan Walikota didalam

\footnotetext{
${ }^{294}$ Ibnu Hajar al-Asqolani, Fathu al-Bari, (Beirut:Dar al-Makrifat,1449), jilid 13, h.123.

${ }^{295}$ Reza AA Watimenna, Menjadi Pemimpin sejati: sebuah Refleksi Lintas Ilmu,(Jakarta timur, Evolitera ,2012), h.35.

${ }^{296}$ Herry subiakto, Komunikasi Politik, Media, dan Demokrasi, (Jakarta: Prenadamedia Group, 2014), h.36 321.

${ }^{297}$ M. Hasim Kamali, Membumikan Syariah, terj Miki Salman, ( Bandung: Mizam, 2008), h.
} 
Bab III Pasal 7 didalamnya berisi tentang Persyaratan Calon seperti yang disebutkan dalam pasal 7 tersebut sebagai berikut: ${ }^{298}$

Warga negara Indonesia yang dapat menjadi Calon Gubernur, Calon Bupati, dan Calon Walikota adalah yang memenuhi persyaratan sebagai berikut:

a. Bertaqwa kepada Tuhan yang Maha Esa

b. Setia kepada Pancasila, Undang-undang Dasar Negara Republik Indonesia Tahun 1945, cita-cita Proklamasi Kemerdekaan 17 Agustus 1945, dan Negara Kesatuan Republik Indonesia

c. Berpendidikan paling rendah sekolah lanjutan tingkat atas atau sederajat

d.Telah mengikuti uji Publik

e.Berusia paling rendah 30 (tiga puluh) tahun untuk Calon Gubernur dan 25 (dua pulih lima) untuk Calon Bupati dan Calon Walikota

f. Mampu secara jasmani dan rohani berdasarkan hasil pemeriksaan kesehatan menyeluruh dari tim dokter

g. Tidak pernah dijatuhi pidana penjara berdasarkan putusan pengadilan yang mempunyai kekuatan hukum tetap karena melakukan tindak pidanayang diancam dengan pidana penjara 5 tahun atau lebih

${ }^{298}$ Undang-Undang Pilkada, (Pustaka Buana,2015), h. 120

Jurnal Al-Dustur; VOLUME 2 NO 2, DESEMBER 2019 
h.Tidak sedang dicabut hak pilihnya berdasarkan putusan pengadilan yang telah mempunyai kekuatan hukum tetap

i. Tidak pernah melakukan perbuatan tercela

j. Menyerahkan daftar kekayaan pribadi

k.Tidak sedang memiliki tanggungan utang secara perseorangan dan atau secara badan hukum yang menjadi tanggung jawabnya yang merugikan keuangan Negara

1. Tidak sedang dinyatalkan pailit berdasarkan putusan pengadilan yang telah mempunyai hukum tetap

m. Memiliki Nomor pokok Wajib Pajak dan memiliki laporan pajak pribadi

n. Belum pernah menjabat sebagai Gubernur, Bupati, dan walikota selama 2 (dua) kali masa jabatan dalam jabatan yang sama

o. Berhenti dari jabatannya bagi Gubernur Bupati, dan Walikota yang mencalonkan diri di daerah lain

p.Tidak berstatus sebagai pejabat Gubernur, pejabat Bupati, dan pejabat Walikota

q.Tidak memiliki konflik kepentingan dengan pertahanan

r. Memberitahukan pencalonannya sebagai Gubernur, Bupati, dan Walikota kepada Pemimpin Dewan Perwakilan Rakyat bagi anggota Dewan Perwakilan Rakyat, kepada pemimpin Dewan Perwakilan Dearah bagi anggota Dewan Perwakilan Daerah, atau kepada Pimpinan DPRD bagi anggota DPRD 
s. Mengundurkan diri sebagai anggota Tentara Nasional Indonesia, Kepolisian Nrgara Republik Indonesia, dan Pegawai Negeri Sipil sejak mendaftarkan diri sebagai calon dan

t. Berhenti dari jabatan pada badan usaha milik negara atau badan usaha milik daerah

Persyaratan warga Indonesia yang dapat menjadi calon Gubernur, calon Bupati, dan calon Walikota. Seorang calon harus memenuhi seluruh syarat yang ditetapkan dalam pasal tersebut, baru berhak diusung sebagai calon, baik melalui partai politik maupun lewat jalur Independen. Secara khusus mari kita perhatikan Pasal 7 butir a, yang mencantumkan syarat seorang calon haruslah orang yang “Bertaqwa kepada Tuhan Yang Maha Esa". Syarat ini sama mutlaknya dengan syarat lainnya, seperti berpendidikan minimal SLTA, berusia minimal 30 (tiga puluh) tahun untuk calon Gubernur dan 25 (dua puluh lima) untuk calon Bupati atau Walikota.

Pasal 7a ini dengan spesifik menyebutkan seorang calon Kepala Daerah, tidak saja harus beragama dengan percaya kepada Tuhan Yang Maha Esa, tapi juga dengan khusus mengatakan harus Bertakwa. Menurut kamus besar Bahasa Indonesia ada tiga macam arti dari kata yang pertama, Takwa adalah terpeliharanya diri untuk tetap taat melaksanakan perintah Allah dan menjauhi segala laranganNya. Yang kedua, Takwa adalah keinsafan diri yang diikuti dengan kepatuhan dan ketaatan dalam melaksanakan perintah Allah dan menjauhi segala laranganNya. Yang ketiga, Takwa adalah kesalehan hidup. ${ }^{299}$

Dari definisi kata takwa tersebut jelaslah bahwa takwa merupakan kata yang mendeskripsikan suatu kondisi dimana orang beragama yang menjalankan perintah

${ }^{299}$ http// www. kbbi.web.id/takwa diakses pada tanggal 25 Agustus 2018

Jurnal Al-Dustur; VOLUME 2 NO 2, DESEMBER 2019 
Tuhan dan menjauhi apa yang dilarangNya. Dalam pasal 7a Undang-Undang nomor 10 Tahun 2016, Takwa yang dimaksud tentu sesuai dengan agama yang dianut masing-masing calon Kepala Daerah. Oleh karenanya sangat jelas dalam UndangUndang ini memerintahkan setiap calon harus memenuhi syarat teratas pertama sekali, calon harus beragama. Dan dengan jelas dinyatakan tidak hanya sekedar beragama tapi juga haruslah orang yang bertakwa sesuai ajaran agama yang dianut.

Syarat Takwa ini sama harus dipenuhinya seperti persyaratan seorang calon Kepala Daerah harus berpendidikan minimal SLTA, haruslah berumur minimal 30 (tiga puluh) tahun untuk Gubernur dan 25 (dua puluh lima) tahun untuk Bupati atau Walikota. Untuk mengetahui bahwa seorang calon adalah orang yang bertakwa, tentu tidak bisa digunakan variable penilaian ketakwaan yang sama antara agama Islam, Kristen, Hindu, Budha, atau agama lainnya. Agama Islam memiliki perintah dan larangan yang tentu ada perbedaan dengan agama lainnya.

Dalam ajaran Islam, seorang Muslim dilarang meminum khamar, minuman berakohol, maka bila seorang Muslim melanggar larangan ini, maka ia termasuk golongan yang tidak bertakwa. Dalam konteks pasal 7a, maka orang tersebut tentu tidak memenuhi syarat sebagai calon Kepala Daerah dipasal 7a, maka orang tersebut tidak bertakwa sebagai seorang Muslim. Demikian juga ketakwaan menurut ajaran agama Kristen, Hindu, Budha dan lainnya. Maka sesuai perintah Undang-Undang kita harus mebawa-bawa agama dalam memilih pemimpin. Karena Undang-Undang mengharuskan kita mengetahui apakah seorang calon adalah orang yang bertakwa sesuai ajaran agama yang ia anut. Tentu seorang Muslim tidak bisa mengukur ketakwaan seorang Kristiani misalnya, begitu juga sebalikya. 


\section{DAFTAR REFERENSI}

Said, Hakim Mohammad. Moralitas politik: Konsep mengenai Negara', dalam A.E. Proyono (ed), Islam Pilihan Peradaban, Yogyakarta: Shalahuddin Press, 1884.

Esposito, John L. Islam and Politics, terj. Joesoef Sou'yb, Jakarta: Bulan Bintang, 1990.

Syarif, Mujar Ibnu. Hak-Hak politik minoritas non-muslim dalam komunitas Islam Bandung: Angkasa, 2003.

Vaezi, Ahmad. Agama Politik Islam Nalar Politik Islam Jakarta: citra,2006.

Saebani, Beni Ahmad. Fiqih Siyasah Terminologi dan Lintasan Sejarah Politik Islam Sejak Muhammad saw. Hingga Al-Khulafa Ar-Rasyidun Bandung: CV Pustaka Setia, 2015.

Al-Maududi, Abu al-A"la. "The Islamic Law and Costitution", Lahore: Islamic Publications, 1960.

Said, Imam Ghazali "Solusi Hukum Islam: Keputusan Muktamar, Munas dan Konbes Nahdlatul Ulama”, Surabaya: Diantama, 2006.

El Muhtaj, Majda. "Hak Asasi Manusia dalam Konstitusi Indonesia”. Cet.1. Jakarta: Kencana,2005.

Khalik, Farid abdul. Fikih Politik Islam Jakarta: Sinar Grafika Ofset, 2005.

Iqbal, Muhammad. Fiqih Siyasah-Konstektualisasi Doktrin Politik Islam Indonesia: Prenadamedia Group, 2014.

Syarifudin, Amir. Garis-garis Besar Fiqih, Jakarta: Prenada Media, 2003.

Rais,M. Dhiauddin Teori Politik Islam, Jakarta: Gema Insani, 2001.

Soekanto, Soerjono. dan Sri Mamudji, Penelitian hukum normatif, Jakarta: PT. Raja Grafindo Persada, 2004.

Hadi,Sutrisno. Metodologi Research Yogyakarta: Andi Offset,1990.

Marzuki, Peter Mahmud. Penelitian Hukum. Jakarta: Kencana Prenada Media Group, 2011. 
Soekanto,Soejono. Metode Penelitian Hukum. T.Cet; Jakarta: UI-pres, 1986.

Lexy, Moleong. Metode Penelitian Kualitatif cet. I; Bandung: Remaja Rozda Karya, 2009.

Muhammad, Abdul Kadir. Hukum dan Penelitian Hukum, Bandung: Citra Adtya Bakti, 2004.

Purwanto, Ngalim dkk. Administrasi Pendidikan, Jakarta: Mutiara, 1984.

Indonesia, Ghalia Pemimpin dan Kepemimpinan, Jakarta: Ghalia Indonesia, 1984.

Rahim, Aunur. Definisi Kepemimpinan dalam Islam, 2001.

Rivai, Veithzal. Kepemimpinan dan Prilaku Organisasi, Jakarta: Raja Grafindo Persada, 2003.

Al-Mawardi, Al-Ahkam Assulthaniyah, Bairut: Dar, Al-Fikr,tt.

Khaldun, Ibnu. Mukaddimah Ibnu Khaldun, Bairut:Dar, Al- Jail,tt.

Attaftazaniy, Saaduddin. Syarhu Al-Makasid Bairut: Dar, al-kutub, al-ilmiyah, 2000 .

Arris, Diyauddin. Annazariyah Assiyasyah Al-Islamiyah, Kairo: Dar, Atturats,tt..

Al-Mawardi, Al-Ahkam Sulthaniyah - Sistem Pemerintahan Khilafah Islam, Jakarta: Qisthi Pers, 2015.

Yahya, Ridwan. Kepimpinan dalam Al Quran, Bandung: Remaja Rosdakarya, 2009.

Achmad Chodjim, Membangun Surga, Jakarta: Serambi Ilmu Semesta, cet, ke-1, 2004.

Zuhaili,Wahbah. Tafsir Munir Fli aqidah Wa syariah Wal Minha, Beirut: Darul AlFikri Al- Ma"sir, jus 23.

As Salus, Ali Ahmad. Aqidah Al-Imamah, Inda as-Syari"ah al-Isna „Asyariyah, Jakarta: Gema Insani Press, 1987.

Syarif, H.M. Mujar Ibnu. "Memilih Presiden Non-Muslim di Negara Muslim d alam Perspektif Hukum Islam", dalam Jurnal Konstitusi, Vol. 1, No. 1 November 2008 
Wawan Gunawan Abd.Wahid, Muhammad Abdullah Darraz, Ahmad Fuad Fanani, "Fiqih Kebinekhaan Pandangan Islam tentang Umat, Kewarganegaraan, dan Kepemimpinan Non-muslim .

Arake, Lukman. Benarkah Islam mengajarkan Politik, h. 243.

Azhary, Prof.Dr. H. Muhammad Tahir SH., Negara Hukum Studi tentang P rinsip-prinsipnya dari Segi Hukum Islam, Jakarta: Prenada Media Group,2003.

Al-Mawardi, Al-Ahkam al-Sultaniyyah, .

Muhammad Abdul Qadir Abu Faris. Sistem Politik Islam. Terjemahan dari Musthalah Maufur, Kitab an-Nizham as-Siyasi fil-Islam. Jakarta: Robbani Press, 1999.

An-Nabhani Taqqiyuddin. Sistem Pemerintahan Islam; doktrin sejarah dan realitas empiric; Terjemahan dari Moh. Mahfud Wachid. Kitab Nidhamul Hukmi fil Islam, Cet I, Bangil: Al-Izzah, 1996

Ridwan HR. Fiqh Politik: Gagasan, Harapan, dan Kenyataan. Yogyakarta: FH UII Press, 2007.

Al-Kattani, Abdul Hayyie Pengadilan dan Mekanisme Putusan, Sistem Pemerintahan dalam Islam, Jakarta: Gema Insani Press,2011.

Lubis, M. Ridwan. “Agama dalam Diskursus Intelektual dan Pergumulan Kehidupan Beragama di Indonesia" Jakarta: Pusat Kerukunan Umat Beragama, Departemen Agama RI

Abdul Rozak, Ubaedillah, "Pendidikan Kewargaan (Civic Education) Demokrasi Hak Asasi Masyarakat Madani”, Jakarta: Perdana Media Group,Cet. ke-5, 2010.

Krissantono, Pandangan Presiden Soeharto tentang Pancasila Jakarta: Yayasan Proklamasi CSIS, 1980.

Prof.Dr.H. Muhammad Tahir Azhary,S.H. Negara Hukum, (Jakarta: Prenada Media Group, Edisi pertama, 2003.

Departemen Agama Republik Indonesia, Al-Qur'an Dan Terjemahan, Semarang: PT. Toha Putra, 2002.

Alwi, Hasan. Kamus Besar Bahasa Indonesia, Edisi Ketiga Jakarta: Balai Pustaka 2002. 
Pusat Pembinaan dan Pengembangan Bahasa, Kamus Besar Bahasa Indonesia, Jakarta: Balai Pustaka, 1994.

Al-Hafidz, Ahsin W. Kamus Ilmu Al-Qur"an Jakarta: Sinar Grafika Ofset, 2006.

Departememen Pendidikan dan Kebudayaan, Kamus Besar Bahasa Indonesia, Jakarta: Balai Pustaka, 1994

M. Quraish Shihab, Tafsir Al-Misbah (Pesan dan Kesan Keserasian al-Qur"an), Jakarta: Lentera Hati, 2004

Tafsirul Al-Qur"anil Adzim, Jilid.I.

Shahih Muslim bi Syarh Al-Na wâwi, Jilid.XII.

Syeikh Imam Qurtubi, Tafsir Al-Qurtubi, terjemahan Dudi Rosyadi, Jakarta: Pustaka Azzam, Edisi ke-IV, 2008. 